\title{
THE ROLE OF THE STATE IN THE IMPLEMENTATION OF DEMOCRACY AND HUMAN RIGHTS IN INDONESIA
}

\author{
Muh. Alfian \\ Muhammadiyah University of Purworejo \\ Email: vian.muh@gmail.com
}

\begin{abstract}
This research aimed to examine to what extent the role of the State participation in applying the principles of democracy and human right in Indonesia. This research is normative legal research (library research). There are two obligations of state toward human rights namely, protection and realization. Protection requires the role's state to guarantee and to protect human rights. Meanwhile, realization is obligation demanded State to act actively in keeping human rights. Human Right violations aren't only done by State, but also non-State actors covering either individual or corporation. The obligation and responsibility to keep human rights are important because we are not only face human crimes, genocide or war crimes but also poverty and undeveloped. The obligation and reponsibility of corporation are realized in the form of Corporate Social Responsibility, especially in community development.
\end{abstract}

Keyword : State, Democracy, Human Rights

\section{A. INTRODUCTION}

Human Rights and democracy are concept of humanity and social relationship which are born from the history of human civilization in the whole world. Human Rights and democracy can be meant as a result of human struggle to maintain and reach the human standing, now only the concept of Human Rights and democracy has proven as the most confessing and guarantying for the human standing as well.

The concept of Human Rights and democracy can theologyly be traced through the human's independency and God's absoluteness. Consequently, there is no human being assumed to occupy the higher position, because only one absolute and it is prima facie, that is God. All human being have the potency to reach the truth, but truism is impossible to be owned by human being, because the absolute truth is only God (The Indonesian Statute Book Year, 1999: 165). Hence all humans' thought also have to be assessed its truth relatively. A thought claiming to be correct absolutely and other mean wrong, is the idea which oppose against the humanity and the infinite.

Humans are created by God with a set of rights guarantying its degree as a human being. This rights is then referred as the Human Rights, which is the rights obtained since its birth as a human being and it symbolizes the grant from The Creator (Franz Magnis-Suseno, 2009: 135). Instead of every human being is created equal with the same rights, so the principle of equality is a major thing in social interaction. However the fact shows that humans always live in the social community to be able to keep the human degree and reach their goals. This matter is impossible to be conducted individually. As a result, the social structure is created. 
It requires an authority to run the social organization.

An authority in an organization can be obtained through religious legitimacy, ideological legitimacy or pragmatic legitimacy. However, the authority based on those legitimacies disobey the human equality because it claims that there is a group of human being higher than other human being. Moreover, the authority which is based on those three legitimacies will become the absolute power because its base assumption place the commanding group as a party which is specially in charge and know more in running the country. The existing authority under the law of the three legitimacies may simply will become the autoritary governance.

The concept of democracy gives the foundation and mechanism for the authority based on the principle of equality for human being. Democracy puts human being as the owner of sovereignty which is then recognized as the principle of democracy. Based on social contract theory, to fulfill the rights of every human being is not possible to be reached by each one individually, but it has to be together. Hence, a social agreement is made containing things that become common goals, individual rights boundary, and the one who is responsible for the attainment of the goals and applying the agreements which have been made with their boundaries (George H. Sabine, 1961: 90). The agreement is carried out in the form of constitution as the supreme law of the State, then being elaborated consistently in the law and policy of the State. The process of democracy is also shown through the procedure of general election to choose the council representatives and other public functionary.

The growth of Human Rights and democracy concept is related to a State of law concept. In its concept, the real authority is the law, not human. The law is considered as a hierarchical unity of norms led to a constitution. It means that in a State of law it demands the existence of constitution supremacy. Constitution supremacy is not only the consequence from the concept of a State of law, but also means the implementation of democracy because the constitution is the highest social agreement form (Jimly Asshiddiqie, 2005: 58-65).

The principles of democracy or sovereignty can guarantee the society participation in the process of decision making, so law applied and upheld really express the feeling of public justice. The law and regulation which are running should not be decided and approved only by one side and only for the benefit the authority. This matter opposes against the principle of democracy. Law is not meant only to ensure the interest of someone who in command, but to guarantee the interest of all people. Thereby, the law state which is developed is not an absolute rechtsstaat, but democratische rechtsstaat.

\section{B. PROBLEM STATEMENT}

As for problems raised in this research : first, what is the urgency of the role of the State in the implementation of Democracy and Human Rights in Indonesia? second, what is the model of the role of the State in implementation Democracy and Human Rights in Indonesia? 


\section{RESEARCH METHOD}

This research is a normative research conducted by library research. The data of this research is secondary data which is law materials. In addition, it is used the secondary law materials, consist of the literatures, journals, result of other scientific masterpiece and research related to this research as well. The research is conducted by document study, analysis, and learn the existing law materials of which its relation with this research, in the form of comprehensive study results in the implementation of Democracy and Human Rights, especially with the relation to the role of the State along with its organs (Johny Ibrahim, $306: 313)$.

\section{RESEARCH RESULT AND DISCUSSION}

\section{Dialectics of The State's Role to Protect Human Rights}

\section{a. Human Rights is a Political Product}

No concept or idea beyond this world is born from an empty room. Every concept or idea has a background and factor influencing its appearance. The motive of that background can be political, economic, social, religion, and also cultural. One thing which is certain is the birth of that concept bringing a certain need, so there is no concept or idea which is sterile or neutral from the intention of the need maker. Hence, it is not surprising when many concepts or ideas which tend to support a certain side and despise other.

Nowadays, such concept of Human Rights can also be told to become something which is objective and accepted by the majority of people in the world. The appearance, formulation and institutionalization of Human Rights, according to Satjipto Rahadjo, cannot be discharged from the social environment or habitat where the Human Rights emerges for the first time. The early documents of Human Rights, like Bill of Rights, Declaration Of the Rights of Man and of the Citizen, and Bill of Rights were born at the era of Renaisance which was happening in the West. As we have known, this period was the enlightment and liberation for the handcuffed individual rights.

The same as the preceding opinion, Rhode E. Howard describes that the suitable approach for Human Rights is with the theory of constructivism, a theory admitting that the rights is not given by God to human being, nature or life event. Human Rights arises from the action of human being and it is a certain moral vision choice about the potency of human being and the institutions to realize that vision. This theory is suitable with the sociological view which sees Human Rights as the social symptoms, a creation of human's thought.

An opinion which considers Human Rights related with the West is not fully correct, because various colonialism practices which have been conducted by the West create the 
paradox related to the West commitment to Human Rights. Besides, the human values which has similarity with the Human Rights actually stated in many traditions or cultures and religions.

A debate regarding whether Human Rights is West or not will lead into the discussion of between universalism versus cultural relativism. This debate ended up to the refusal of the relativists on the claim that Human Rights is universal, applied to whoever and anywhere. They think that a cultural construction and different tradition will create the view about everything which is also different. Therefore, to the relativist group, there is no universality of Human Rights, because every society has their own Human Rights.

Basically, Human Rights should be meant as a "concept" about a protection action to human values. With this starting point, hence what yielded by United Nations, what is later being called Human Rights, is only one of the concept on how to protect the human values. If the one who made the concept was not the United Nations, it is possible that its name will not be Human Rights and its form will not be what can be seen right now. The concept of defending the human beings can take other form and name depending to whom and to what purpose that the concept is compiled. So that, it is not surprising if then there are various perspective which emerge about Human Rights, like from Islam, Third World, marginal group, even the State.

By using this perspective, hence the objection of relativist group toward Human Rights concentrated to Human Rights compiled by United Nations and it is not the Human Rights which is understood as the protection concept to the values of humanity. Likely, though its form is not Human Rights, the majority of relativist groups which are most of them are from the Third World remain to acknowledge that there is an obligation to improve the protection concept toward human values. What is universal from Human Rights is actually the spirit of protection to the human.

According to the political and legal perspective, Human Rights is believed to have an inherent character inside the human being and it does not need another justification again from the state, but to translate and then execute it, Human Rights is still require a positivism. Discussing about positivism, hence we in fact are talking about forming process of law. The law as a dynamic process always represents the political process. Making a law, for example, it will entangle with other intentional groups and politics party which sits in the parliament. Hence, it is not surprising if there is an assumption that the law represents the political product, where a certain political configuration will influence the characteristic of the law.

Beside of that, it is based on the theory above, this assumption is also pulled from the historical fact of Human Rights appearance. The Human Rights Concept was proposed by the modern nations. Human Rights attends as the massive awareness and becomes global since the modern nations at that moment involved with a conflict in War World II, then 
they merged into the United Nations, announced the Declaration of Human Rights (UDHR) in 1948.

UDHR itself, then followed by various convention of United Nations, was born from an international legislative process entangled with lobbying, even compromising. Legislative process is always represents the political process and the state becoming the single most institution which has the right to deal with it. According to Forsythe, the effort to make the Human Rights principles and implementation represents a political process. Meanwhile, Ivo Duchacek, as cited by Forsythe, explains that a dinamic energy which supports the making of Human Rights constitution first of all is political dinamic energy. Even though it is high matters about the constitution similarity of constitution but it is related to the problem of politics, that is who leads whom, for what purpose, by what means and how it operates.

From the above presentation, it is seen that various UN Human Rights regulation or Convention, as the national regulation, born from a political process. The difference is, at the formulation of national regulation that the one which has the role is the political party, while at the formulation of UN Human Rights regulation, that role is hold by the state. The state, in the formulation of Human Rights Convention, becomes the party which has the biggest authority. That is also why at the step of implementation, the latest applicable International convention will only has been ratified by the state institution.

As any international law in general, the law system in Human Rights gives a big authority for the state. In the case of Human Rights collision, for example, it is true that the Human Rights law system provides the procedure in so many Convention for someone to be free from the pressure of other party. Nevertheless, instead of the straightening of Human Rights conducted by United Nations is very dependable on the political pressure, the State itself, rather than individual, is responsible to the Human Rights collision. The position of the state becomes dominant progressively since there is no interpol which gives someone a place to claim about their government. International justice in Den Haag only hears a case from the state rather than individual.

With this dominant position, the state is then given the responsibility for the implementation of international Human Rights regulation. Every rights is true ever claiming the existence of obligation, and that Human Rights obligation is taken by the state. The first phase from fulfilling this obligation is demanding that the state ratifies various convention of United Nations Human Rights and including the problem of Human Rights into the national constitution. The convention represents the definition of Human Rights concept and ties the inter-states agreement and also gives the behavior standard for the government executing it. By ratifying or agreeing the convention, the state agrees to guarantee that Human Rights expressed in the convention has been felt by each and everyone in the region. 
After ratifying the convention, the signatory state is obliged to execute the convention rule. At this phase, some convention have the free choice protocol and some others do not enable the existence of objection element. However, the matter 'which is important to know, is that though the state has already ratified or joined in the convention, this does not judicially oblige the state to fulfill any responsibilities in the convention. It means, as discussed previously, the execution mechanism of convention, and generally the straightening of Human Rights, needs more political effort than the law. In a condition like this, the state's political will in the execution of convention rule becomes the central.

\section{b. The Types of State's Role in Human Rights}

Generally, the role, or more precise, the state's obligation in Human Rights can be divided into two fundamental duties, protection and realization. Protection makes the state to guarantee and protect the Human Rights. This obligation is often called as the negative rights, where the state, in this case, has a passive character. The state only gives the regulation constitutionally so that all its citizens can enjoy the basic rights which is ought to be owned by them. The opinion expressing that this type of obligation does not require high expense is not fully correct. A guarantee and protection are also enough to make the state fumble for their expenses because the structure of justice enforcer and the law like police, courts, training of lawyer and judge, the law system access, and the society resuscitation about rights, all them cost a lot of money. Meanwhile, realization is an obligation forcing the state to act actively in fulfilling the Human Rights. Compared to the first obligation model, this obligation type needs a larger energy and expense.

Shortly, the state obligation in Human Rights can be categorized in 3 (three) levels, which are the obligation to respect, protect and fulfill. If the obligation of "respecting" basically limit the state's role, on the contrary, obligation "fulfilling" obliging the state to behave actively with the aim to to strengthen the society access to the resource. This obligation is the most claiming obligation of the state's intervention (positive measures) so that it is guaranteed that everyone will obtain their rights which cannot be fulfilled through their own effort.

\section{Human Rights Classification and Its Implication to The State's Role}

a. The First Generation Domination (Civil and Political Rights) and The Lameness of The State's Role in Guarantying and Fulfilling Human Rights

The classification of Human Rights have been divided into three generations through its growth creates the first generation domination which consists of the civil and politics rights which were taken from the liberal tradition of Western countries. The social history and politics of the world are influenced by West domination. Various idea of philosophical and social concept from Western have disseminated to all over the world, 
included in this matter, Human Rights. Therefore, it is not surprising that in the case of Human Rights implementation, the first generation which is born from the womb of liberal Western civilization, becoming dominant. When people talk about Human Rights, it is only about civil and political rights. It is also when all politicians and mass media discuss the Human Rights report from a state, they seldom mention the rights from either second or third generation, like the rights of health service, the rights of education, the system of social security or the rights of healthy environment. The domination of the first generation toward Human Rights can also be seen from the existence of fact that these rights are almost dominant in the entire international declaration and covenant which had been specified by United Nations since the World War II.

The implication from this domination related to the state's role is the lameness of the state's commitment and attention in guarantying and realizing the Human Rights. The rights which is protected and realized often only limited to civil and political rights, even economic rights, social and cultural are often assumed as non rights. This fact starts from the assumption that the accomplishment of civil and political rights is considered as negative rights, so it does not need the state's intervention in protecting it. The state is put itself down in a passive position and only conducts an obligation on the protection. Whereas, the accomplishment of economic, social and cultural rights considers as the positive rights which needs an active role from the state with high expense.

The emerge of this difference is because of the difference on the law formulation used between ICESCR and ICCPR. In ICESCR, the formulation used is "undertakes to steps to maximum of its available resources, with a view to achieving progressively the realization of the rights recognized in the present covenant. Meanwhile, in ICCPR the formulation used is "... individual undertakes to respect and ensure to all [of] within its territory and subject to its jurisdiction in the present covenant. The difference in the law formulation which became a reason to draw a distinguishing line between economic, social and cultural rights with the civil and political rights.

Besides, no optional protocol at economic, social and cultural rights, as it is found at civil and political rights also strengthen the assumption that the rights which should be given the high priority and fulfilled immediately are civil and political rights, whereas economic, social and cultural rights can be fulfilled later.

The concept made by Western countries as Human Rights, according to Jim Ife, constructed through some views, for example individualism, patriarch traits, colonialism, racism and its progress, rationalism, and culturalism. These views construct how the state ought to take the role in Human Rights accomplishment which later creates the lameness in the state's responsibility. This difference in fact represent the direct glimpse from Western liberal political view, laissez faire, placing the state as the passive side in economic business. 
In radical liberalism, economic rights is assumed as non rights. Only the rights of civil and politics which are considered to be a real Human Rights. Maurice Cranston, as cited by Rhoda E. Howard, expresses the coherent of economic and social rights (which cannot be reached) removes the civil and political rights from its moral demand and place it on the gloomy utopia aspiration, which will bleach the Human Rights principle. While Carne Lord, proposes that social and economic rights should be erased. There are two reasons for this, first, the government will still be able to guarantee their rights of civil and politics when they cannot guarantee the economic rights. Second, the priority of civil and politics rights has to be upheld clearly (Kelsen, Hans. 2013: 80-83).

As the glimpse of this lameness, there are a lot of economic, social and cultural rights which are not fulfilled. In rich Western countries, like United States, there are still many found a high poverty, homeless people, and racism. Based on the report of International Forum on Globalization, in United States which represents the major state initiator of globalization, all benefits are taken, especially by the rich executive board. They come from various giant corporations. Meanwhile, the curve of injustice in the case of earnings and properties distribution also accelerates fast and strikes all people. The gap between the high executive board to the worker reaches the highest record of level.

This matter happens because United States does not mention the economic rights in its constitution. According To Rhoda E. Howard, in America the civil and political rights and also proprietary rights are protected, but the economic, social and cultural rights are assumed quite abundant. The fund for social prosperity is very small compared with the fund for the security of defense. Besides that, United States until now has not yet ratified the ICESCR which arranges and claims the nations which have signed it for realizing economic, social and cultural. So, Mary Ann Glendon concludes that a differentiating factor for a prosperous state like America is whether there is a constitutional intention to protect its citizen or not.

b. The Indivisibility of Human Rights: An Alternative Thought on The State's Role in Economic, Social and Cultural Rights Accomplishment

In the middle of first generation domination which implies the lameness of the state's attention and role in Human Rights accomplishment, it flows an alternative idea about how to look into the classification of rights in Human Rights. On this matter, Human Rights is born in one package and has indivisible and universal character, which cannot be separated individually. All existing rights in Human Rights are important and there is no rights more significant than the others.

All rights in Human Rights are interacting one another and become the important factor to maintain the human being prestige. For example, the demand of education rights is a part of economic, culture and social rights can only obtain the maximum result when the government can be influenced through the public opinion. To assure others and the 
government about the good education campaign, it needs civil and political rights in the form of the right to submit the opinion freely. The civil and political rights, according to Mc chesney is actually a joined forces with a economic, social and cultural rights as one package from UDHR. Though both Human Rights group arranged in two different covenants, but each started by the same introduction emphasizing the implementation of both group of rights for everybody.

Based on this idea, many experts in making the classification of Human Rights do not emphasize to the three generation made by Vasak. Sieghart, cited by Eide in which has divided the Human Rights based on the rights which need to be protected. He specifies several things as the protection target, those are 1) physical integrity 2) the life standard 3) health 4) family 5) the job 6) social security, aid and prosperity 7) education and training 8) property 9) integrity law 10) moral and mental integrity, 11) actions with ( the right to join an association, gathering and forming a labour union), 12) politics and democracy, and 13) collective rights. This Sieghart's classification cut the dichotomy between the civil and political rights in one side, and the economic, social and other cultural rights in other side. However, like he explains that a different classification of rights and it should be used carefully. Mostly Human Rights are connected and reach different aspects from their three main focuses; integrity, freedom and equality status of all human being.

Related to the state's role in the accomplishment of economic, social and cultural rights, Eide expresses that UDHR forces at least a moral obligation to all the state in realizing the fulfillment of economic, social and cultural rights. More importantly, in section 2 ICESCR, the participant nations have the legal obligation and are tied to take actions toward the available resource management maximally and progressively can fulfill the economic, social and cultural rights. The term "progressively" is often interpreted wrong. On the general comment in 1993, Economic, Social and Cultural Rights Committee emphasized that the phrase had to be seen in a whole target's point of views, which determines a clear obligation to a participant state to take action as soon as possible toward the accomplishment of the rights.

As related to the assumption that the accomplishment of economic, social and cultural rights needs a lot of money weighing the state actually starts from the limited understanding about these rights. The state's obligation, according to Eide, has to be seen through the view of economic, social and cultural rights, individual is an active subject. The accomplishment of these rights is usually conducted in a household context as the smallest economic unit. Based on this matter, Eide then gives a kind of steps for executing the state's obligation in economic, social and cultural rights.

At the first level, the state has to respect the resource owned by every individual, or someone's freedom to get the favorable work and freedom to take an action which is 
needed and also use the resource which is needed for himself, or cooperated with others, to fulfill its own requirement.

The second phase includes, for example, a protection of freedom to act and use the resources from more aggressive subjects, against the demand from the economic leaders. The state's productive function is one of the state's most important obligation aspect related to the economic, social and cultural rights, and this is similar with the state's role in protection of the civil and political rights. Therefore, the important component at this second phase is an obligation "protecting" which is explained in the law and constitution.

While at the third phase, the state has the obligation to assist and fulfill. The obligation "assisting" can be conducted in so many forms, some have been explained in ICESCR and other various rules. For example, section 11 subsection (2) in ICESCR, where the state is told will take action to improve the production, conservation and food distribution activities, by using fully technical and scientific knowledge and by renewing the agriculture system. As for the obligation "fulfilling" can be conducted by providing the requirement of food or resource which can be used as food (direct food aid and social security).

Not only dividing the steps of the state's obligation in economic, social and cultural rights, Eide also affirms that the assumption mentioning that civil and political rights reside in the first phase (respecting), while economic, social and cultural rights reside in the third phase (fulfilling), is an unconscious scenario. Some civil rights require the state's obligation at all level, including the obligation to provide the direct aid if there are any requirement for that. Social and economic rights, on the other side, in most cases can be strived through the action of non-state intervention toward the freedom and the resource usage owned by every individual.

Furthermore, Ifdhal Kasim explains, in economic, social and cultural rights, the state does not always have an active character, at a certain time the state is also needed to be passive. There is no differentiation against the state's responsibility in the accomplishment between economic, social and cultural rights with the civil and political rights. Both affirm either the obligation of result and the obligation of conduct. This matter is relied on the fact that economic, social and cultural rights are not only the positive rights, because besides arranging type of the right to, ICESCR also arranges the rights in type of freedom from.

The state's obligation in economic, social and cultural rights by using the approach which sees the economic, social and cultural rights are not only as the positive rights elaborated in detail by a group of experts in a meeting which was performed by International Commission of Jurist in June 1996 yielding Limburg Principles. This document affirms that though ICESCR specifying the attainment step by step and confesses the available resource limitation, on the other side there are also rights which 
must be fulfilled immediately. Besides Limburg Principles, International Commission Jurist also performs a meeting there in 1997 in Maastricht producing Maastricht Principles, representing about the violation of economic, social and cultural rights. Both of this guidance according to Ifdhal Kasim have terminated the interpretation which arbiter toward Economic, Social and Cultural Rights Covenant.

In the accomplishment of economic, social and cultural rights, according to Mcchesney, there is no exception for the poor countries in fulfilling Human Rights. The poorness of the state is not a reason in order not to fight for this rights. Even, Covenant has affirmed toward the poor nations to do more effort than the rich nations. The lack of resources does not lessen the obligation of the participant states to guarantee at least minimum level from economic, social and culture rights. This point of view has been told by The Committee of United Nations at the Economic, Social and Cultural Rights which is so-called General Comment, being a guide to the participant states in order to be more comprehending of their obligation in fulfilling the rights in ICESCR. General Comment number 3, written in 1990 entitled On the Nature of States Obligations, it aims to assist the state's comprehension on what must be done in fulfilling section 2 Covenant. General Comment 3 explains some examples of minimum obligation of a state, for example, main health treatment and basic education.

The fundamental matter and closely related with the accomplishment obligation of economic, social and cultural rights by the state is the problem of violation. The state is told violating the Human Rights if it fails in respecting, protecting and fulfilling the rights contained in Covenant. In this case, the Limburg Principles gives a kind of guidance to determine exactly how an obligation violated by the state, that is:

1. The state fails to take the compulsory steps which should be done.

2. The state fails to eliminate quickly the obstacles where the state is obliged to escape it.

3. The state falls down on the job without delaying again the rights obliged for its immediate accomplishment.

4. The state intentionally fails to fulfill a common attainment standard which is internationally accepted.

5. The state applies a boundary toward the rights confessed in Covenant.

6. The state intentionally delays or stops the rights accomplishment partially.

7. The state fails to raise a report obliged by Covenant.

From above description, the state's role in guarantying and fulfilling all existing rights in Human Rights does not have the differentiation significantly. All rights are obliged to be guaranteed and fulfilled, without seeing the rights type. The state also can have an active character (with the intervention) and also passive (by non-intervention) depending on the situation. The rights accomplishment in Human Rights by the state 
basically is very dependable on the government's political commitment and willingness. Besides that, the accomplishment is also very dependable on the politics system used. At the nations with the liberal system, the state tends to be reluctant to regulate the policy which mingles in the economic business.

As having been successfully formulated in the second change of the Constitution 1945 , the rules concerning human rights have received a very strong constitutional guarantee from the Constitution. Mostly this Constitution items in fact come from the law formula which has been ratified previously, that is a constitution about Human Rights. If re-formulated, the items adopted into the Constitution 1945 will include 27 items as following:

1. Everyone has the right to live and also maintain to live on and his life.

2. Everyone has the rights to form a family and continue his offspring through a legal marriage.

3. Every child has the rights to the continuity of life, grow and expand and also the rights of protection from violence and discrimination.

4. Everyone has the rights to be free from a discriminative treatment on all causes and has the rights to get the protection from it.

5. Everyone is free to embrace a religion and to worship according to his religion, to choose a teaching and education, to choose a job, to choose a nationality, to choose a residence in the state's region and leave it, and also has the rights to return.

6. Everyone has the rights of freedom to believe the trust, to express mind and attitude, according to his conscience.

7. Everyone has the rights of freedom to join an association, to gather, and to release an opinion.

8. Everyone has the rights to communicate and obtain the information to develop the person and his social environment and also the rights of looking for, obtaining, owning, keeping, making, and submitting the information by using all available type of channel.

9. Everyone has the rights of protection for oneself, family, honor, prestige, and the goods under his power, and also the rights for the security and protection from the threat of fear to do or fail to do something representing the basic rights.

10. Everyone has the rights to be free from the persecution or humiliating treatment which lowered his prestige as human being and the rights to obtain a political asylum from other state.

11. Everyone has the rights to have a secure and prosperous life physically and mentally, residing, and getting healthy and good environment and also the rights to obtain the health service.

12. Everyone has the rights to get the special treatment and amenity to get the same 
opportunity and benefit to utilize for reaching the equation and justice.

13. Everyone has the rights to have the conducive social security for his development completely as a prestigious human being.

14. Everyone has the rights to have the personal property and the property may not be taken over arbitrarily by whoever.

15. Everyone has the rights to develop himself through the accomplishment of his basic requirements, the rights to get the education and obtain the benefit from science and technology, cultural and artistic, for improving the quality of his life and the welfare of mankind.

16. Everyone has the rights to improve himself in order to fight for his rights collectively to build the society, nation and his state.

17. Everyone has the rights for the admittance, guarantee, protection, and fairness of law and also the same treatment before the law

18. Everyone has the rights to work and also receives the payment and the fair treatment at work.

19. Everyone has the rights on the civic status.

20. The state, in any states of condition, cannot lessen someone's rights to live, the right not to be tortured, the rights of independence of mind and conscience, the rights to believe in, the right not to be enslaved, the right to be admitted as a person before the law, and the right not to be claimed on the basis of withdraw-applicable law.

21. The state guarantees the respect to the cultural identity and traditional society rights in harmony with the epoch growth and the nation civilization

22 . The state highly respects the values of human moral and ethics taught by every religion, and guarantee the independence of every resident to embrace and run their religion teaching

23. Protecting, improving, straightening, and the accomplishing of human rights are the state's responsibility, especially the government.

24. For improving, for upholding and protecting human rights according to the principles of the state upheld the law democratically, hence the execution of human rights is guaranteed, arranged and poured in the law and regulation.

25. To guarantee the execution of section 4 subsection (5) mentioned above, it is formed a National Commission of Human Rights having an independent character according to rules which regulate.

26. Everyone is obliged to respect the others' human rights for the life order inside the society, nation, and state.

27. In applying his rights and its freedom, everyone is obliged to obey to the democracy boundary specified with the law solely for the purpose of guarantying the admittance and also respecting the rights and others freedom and to fulfill the fair 
demand according to the moral consideration, religion values, security, and public order in a democratic society. (The Legislative Decision Number IX/MPR/2000).

If the 27 rules adopted into the Constitution extended by including new elements having the character of completing the existing formula, then re-grouped in order to cover the new rule which has not yet been loaded in it, so the formula of human rights in Constitution will be able to include five item groups as followings:

a. A Group of Civil Rights which is able to be formulated to become

1) Everyone has the rights to live, to keep living on and his life.

2) Everyone has the rights to free from the persecution, cruel punishment or treatment, which is inhuman and condescending human prestige.

3) Everyone has the rights to be free from all kind of slavery.

4) Everyone has the rights to embrace the religion and to worship according to his religion.

5) Everyone has the rights to be free of having a belief, mind and conscience.

6) Everyone has the rights to be admitted as a person before the law.

7) Everyone has the rights to have the same treatment before the law and governance.

8) Everyone has the rights not to be sued on the basis of withdraw-applicable law.

9) Everyone has the rights to form a family and to continue his offspring through a legal marriage.

10) Everyone has the rights on the status of nationality.

11) Everyone has the rights to be free residing in his state region, leaving and back to his state.

12) Everyone has the rights to obtain the political asylum.

13) Everyone has the rights to be free from all kind of discriminative treatment and the rights to get the law protection from the discriminative treatment.

Toward the civil rights, in any states of all, the state cannot lessen the rights determined in Group 1 " a" up to " h". However, the rules do not mean and cannot be interpreted or used as the basis for releasing someone from the prosecution of a confessed heavy human rights violation according to the rules of International law. This limitation and emphasizing are important to ensure that the rules are not exploited without considering by the side trying to be free from the prosecution threat. Here is exactly the controversial situation arising out after the rule section 28 I the second amendment of Constitution 1945 ratified several times ago.

a. b. A Group of Political, Economic, Social and Cultural Rights

a. 1) Every citizen has the rights for joining an association, gathering and expressing his opinion in peace. 
2) Every citizen has the rights to choose and be selected for the institution of people representative.

3) Every citizen can be lifted to occupy the public position.

4) Everyone has the rights to obtain and choose a legal and decent work for humanity.

5) Everyone has the rights to work, get a reward, and receive a decent treatment in the job relationship equally.

6) Everyone has the rights to have the personal property.

7) Every citizen has the rights toward the social security required for a decent life and enable for his development as a prestigious human being.

8) Everyone has the rights to communicate and obtain the information.

9) Everyone has the rights to obtain and choose teaching and education.

10) Everyone has the rights to develop and obtain the benefit from science and technology, cultural and artistic to improve the quality of life and the welfare of mankind.

11) The state guarantees the respect toward the cultural identity and local society rights in harmony with the epoch growth and the nation civilization

12) The state admits every culture as a part of national culture.

13) The state upholds the values of human moral and ethics taught by every religion, and guarantees the independence of every citizen to embrace and run his religion teaching.

c. A Group of Special Rights and Rights on the Development

1) Every citizen having a social problem, including a detached society group and living in a cloistered environment, has the rights to have a special treatment and amenity to get the same opportunity.

2) The woman rights is guaranteed and protected to reach the equivalence gender in the national life.

3) A special right related to the woman's body which is because of her reproduction function is guaranteed and protected by the law.

4) Every child has the rights for the affection, attention and protection of parents, family, society and the state toward their growth physically and mentally and also for someone's development.

5) Every citizen has the rights to participate in the management and take a part for enjoying the benefit obtained from the natural resources management.

6) Everyone has the rights for a healthy and clean environment.

7) The policy, tentative special action or treatment and written in a legal regulation are meant to equalize a certain group growth level which has experienced a discrimination treatment with other groups in society, and a special 
treatment as determined in subsection (1) this section, is not included in the discrimination congeniality as determined in Section 1 subsection (13).

d. The State's Responsibility and Basic Obligation of Human Being

1) Everyone has the rights to respect the other's human rights to live orderly in the society, nation, and state.

2) In implementing his rights and freedom, everyone has the obligation to obey the boundary specified by the law for the purpose of solely guarantying the admittance and respect on the other's rights and freedom and also to fulfill the justice demand according to the religion values, morality and ethics, public orderliness and the security in democratic society.

3) The state is responsible for the protecting, presenting, straightening, and accomplishing of basic human being rights.

4) To guarantee the human rights execution, it is formed a National Commission of Human Rights having an unbiased and independent character which its forming, formation and position are regulated by the law.

The rules giving constitutional guarantee to human being basic rights are very important and even assumed to be one of the fundamental characteristic taken as the principle of law in a state. Besides the basic rights of human being, it must also be comprehended that everyone has the obligation and responsibility which is also fundamental. Everyone, during his life since before birth, owns real rights and obligations as a human being. The forming of a state and governance, to any reasons, may not eliminate the principles of rights and obligations owned by every human being. Consequently, that rights and obligations guarantee is not determined by the people's position as a citizen of a state. Everyone, anywhere he resides in has to be guaranteed his basic rights. At the same time, everyone anywhere he resides in, is also obliged to respect the basic rights of others properly. The balance awareness about his basic rights and obligations is the important characteristic of Indonesian point of views concerning a human being and a justice and civilized humanity.

Indonesian country comprehends that The Universal Declaration of Human Rights triggered in 1948 was a mankind's statements having universal values which is obliged to be respected. At the same time, Indonesian nation also considers that The Universal Declaration of Human Responsibility stated by Inter-Action Council in 1997 containing the universal values which are obliged to hold high to equip The Universal Declaration of Human Rights. The common awareness regarding the basic human rights and obligations that influenced Indonesian law system and constitution, consequently, it requires to be adopted into the constitution formulation on the basis development by Indonesian nation. In consequently, its formulation in this constitution includes the thought heritage of concerning human rights in the past and also including idea which still develops in future 
period.

\section{The Growth of Democracy and Human Rights}

Since the beginning of the 20th century, the aspiration curve has flown up toward the mankind freedom and independence from the tyranny of colonization which highly arose and opened by using the knife of democracy and human rights as an effective struggle and freedom instrument. That top of human struggle has yielded the very extensive and fundamental changes at the middle of the 20th century with the appearance decolonization in all over the world and made many countries to stand up and form new nations which have their independence and sovereign in various parts of the world. The growth of democracy happened again and became stronger after the cold war marked by the collapse of the communist power in Uni Soviet and Yugoslavia. This matter later was followed by the democratization process in the third world nations in 1990s (Samuel P. Huntington, 1991).

All the events pushing the appearance of freedom and independence movement always have the marking of tyranny and injustice power, either inside the structure of relationship between nations or a relationship between a government toward its people. In a struggle discourse for independence and human right from the early until middle in the 20th century which could be easily is the struggle of the colonized nations to face the colonist nation. Consequently, the people in all colonized states easily arose their spirit to be together in one solidarity movement of anti colonization (Huntington, Samuel P, 1991: 10).

While the more uppermost during the second bill of the 20th century was the struggle of people against the governance authority. The discourse of democracy and nationality in a certain state, it must not identical with the people idea in other states which are more developed and have enjoyed the more democratic life. Henceforth, the discourse of democracy and human rights nowadays is also used, either by the people who are under pressure and also by other nation governments which feel they need to promote the democracy and human rights in other nations assumed undemocratic.

Consequently, the link pattern of power between states and the struggle alliance in the past and present time has experienced the fundamental structural change. Once, the international relation played mostly by the government and people were put in the relationship which was divided between the relation of Government to Government (G To G) and the relation of People to People (P To P). Now, that relation patterns turn into various types, either G to G, P To P and also G to P or P to G. All possibilities can be happened, either by the initiative of governance institution and or by the initiative of ordinary civilian. Even other state governance can act to protect the civilians of another state on behalf of human right protection (Jimly Asshiddiqie, 2005).

In other words, the first problem which we face these days is the understanding human rights concept shall be seen in the appropriate context of corrected perspectives of power. 
Even, the concept of the power relation has also experienced the change related with the fact that the power elements these days are not only related to domiciling politics but also related to the power of economic resources, and even technology and industry which show the more important role these days. Therefore, the concept and procedure of human rights these days have to be seen not only from its contextual relation in political power, but also have to be related to an industrial and economic power contextual (Anthony Giddens, 2003).

Because of that, the new relation pattern of power can be seen as a production connection relating between the need of producer and the consumer's need. In industrialization era which increasing constructively because of the improving science and technology these days, the dynamics of production and consumption process this continued still expand in all sector of social and political life these days. A political policy, for example, not only can be seen with the ordinary eyeglasses, but also can be seen as a context of production. The state, in this case is the producer, while the people are as its consumers. Consequently, nowadays human rights conceptually can be comprehended as the consumer rights which must be protected against the exploitation for the shake of the producer's benefit and need.

Because of this matter, the human rights concept and procedure should be related to the following problems (Asshiddiqie, 2005: 70):

a. The power structure in inter-states relation which these days can be told it is very lame, inequitable, and only tends to give profit to advanced nations or controlling nations which dominate the decision-making processes in various international boards and forums, both for the concern of political need and also economic and cultural need.

b. The undemocratic power structure in internal environment of the nations applying authoritarian system which only benefits several top class civilians or the civilians who mastering the economic resources.

c. The unbalanced structure of power relation between the investors with the workers and between the investors along with the production management with the consumers in every world industrial corporation environment, either primary industry, manufacture industry and also industry service.

Some factors being able to cause the relation pattern " top-down", either local, national, regional and also global level for example is the factor of properties and economic resources, political authority, level of education or intelligence rate, mastering of science and technology, image or good name, and physical strength including military strength. The more the above factors mentioned mastered by someone, a group of people and or a nation, it will give the higher position in stratification or association level (Hart, H.L.A, 2013: 24-30). On the other sides, the higher position of someone, a group of people or a nation above other groups or others or other nations, it will give a bigger power owned and it will also give higher potency to treat others arbitrarily for their own benefit. In the lameness of relationship between developed countries with the developing countries, a government with its civilians, 216 Yustisia Vol. 6 No. 1 January - April $2017 \quad$ The Role of The State In The Implementation of ... 
and even between investor or entrepreneur with its consumer where the injustice will surely happen and it will force the emerging of human rights movements everywhere. Hence, one of the undeniable important aspect related to the human right problems is that this problem is tightly connected with the dynamics of class struggle (taken from Karl Marx's term) claiming for justice.

It is often told that the human rights concept lies in the history of international law instrument history at least have been through three generations of development. All three generations of the human right concept development is (Asshiddiqie, 2005: 90)

First Generation, an idea concerning a concept of human rights which has been developed in the scientist's discourse since enlightenment era in Europe, improved into legal international law documents. The peak of this human rights development for the first generation was when the process of signing on the manuscript of Universal Declaration of Human Rights proposed by United Nations in 1948 after previously that the idea of human rights protection contained in historic manuscripts of some nations, as in English with Magna Charta and Bill of Rights, in United States with Declaration of Independence, and in French with Declaration of Rights of Man and of the Citizens. In this first generation concept. the basic element of the human rights concept includes the principal problem of the integrity of human being, basic needs of human being, and principle of civil and politics freedom.

At the next growth which can be called the Second Generation Human Rights, besides the existence of International Covenant on Civil and Political Rights, which the concept of human rights also include the effort to guarantee the accomplishment of requirement to pursue the economic growth, social and culture, including rights on education, the right to determine the political status, the right to enjoy the scientific invention, and others. The culmination to these both growth reached when International Covenant on Economic, Social and Cultural Rights was signed in 1966.

Then in 1986, it also emerged a new concept human rights which included the definition about the rights to development. This rights to development includes the equal right or opportunity to improve for all nations, and including the everyone's rights to live as the part of the nation life. This right to development, for example, covers the right to participate in development course, and the right to enjoy the development result, the right to enjoy from the economic growth result, social and culture, education, health, earnings distribution, working opportunity, and others. This new concept by all experts conceived it as the third generation human rights concept.

However, the third generation human right concept mainly has the same characteristic, which is comprehended in the context of a vertical power relation, between people and government in a state. Every violation to human rights starts from the first generation until third is always entangled with the ordinary government's role categorized as a crime by government which includes into the definition of political crime as against the definition of 
crime against government (evilness to formal power). Henceforth, what is always becomes the target of the human right struggle is the state's repressive power to its people. However, in the present and future growth, as elaborated above that human right dimension will change to be more and more complex character.

The problems of human rights is not comprehensive if we only understand it inside the context of vertical power relation but it should also include the horizontal human right power relation, between society groups, between the factions of people or society, and even between one society group in a state with the society group in other state.

This new conception is the one that I conceive it as the Fourth Generation human rights concept which I have elaborated some part of it at the former part. Even as an alternative, according to my opinion, this last concept of human rights is the one that precisely to be conceived as the Second Generation of Human Rights Concept, because the characteristic of power relation which is arranged is different from the previous Human Rights concepts. The characteristic of power relation in the First Generation concept has vertical character, while the character of power relation in the Second Generation concept is horizontal. Thereby, the definition of the second generation Human Rights concept and third generation previously are quite comprehended as the same growth variant in the growth phase of the first generation concept.

Before the ending of the 20th century, we witness the appearance of some new phenomenon which have never been or had attention in previous periods. First, we witness the appearance of joint venture phenomenon among various big scale companies in a state which then become into the Multi National Corporations (MNC'S) or also called as Trans-National Corporations (TNC'S) everywhere in all over the world. The phenomenon of network power of this MNC or TNC is through very wide regional, even wider than the reach of the state's power, even for a small state which its number are plenty in this world. Related to these big companies' power, what actually becomes our problem is the implication generated from the capital power which exists behind these big companies toward the consumers' need for the product produced. In other word, the power relation questioned in this case is the power relation between the producer and the consumers. The problem is how those rights or the consumers'. needs are insurable, so that the production process can be continuously developed by guaranteeing the consumer rights which also have to be viewed as an important shares from our understanding about the human rights (Giddens, Anthony. 2003: 68-72).

Second, the 20th century has also arisen the phenomenon of Nations without State, like the Kurds which are spread all over in various states of Turkey and Iraq; the Nationalist Chinese who are spread over in very large number in most of all states in the world; the Persians (Iran), Iraqis, and Bosnians who are forced to travel everywhere because the politics problems which they face in their home countries. The law problem of their nationality status 
for the civilians which are forced to reside everywhere, formally truly it can be overcome based on the appropriate law. For example, the Kurds who live in Northern Iraq have, of course, Iraqis nationality, they who live and remain in Turkey, of course, have Turkish citizenship, so they who live in other nations can enjoy the nationality status in which state they live. However, their nationality problem is not formally solved at that moment because of the law arrangement.

Third, in its relation with the first and the second phenomenon above, it started at the end of the 20th century had also developed a certain social strata on every society in the nations actively involved in international association, that is a group who can be called as global citizens. Their number originally is little and it only consists of groups of diplomatic corps which develop their own association groups. Among them also with their families, especially all career diplomats which grow in diplomat career going away from one state to other state, it is formed a separate association network which later becomes a separate social class which is separated from a broader society environment (Ferejohn, John, 2001: 102). For example, in every state, there is what being called as diplomatic shop which is free tax, particularly serves the needs of all diplomat to go shopping. All these strengthen the tendency of a separate social class appearance forcing the new life appearance among the diplomats.

At the same time, among all foreign entrepreneurs who invest capital as the business investors in various states, it is also formed a separate social class as the diplomatic corps does. Even, there are many among workers and or foreign entrepreneurs whose duties continuously beyond the sea, going about from one state to other state, that their association reach is more suited with the world of diplomats like have been mentioned above, than associating with the inhabitants of a nation where they work or even try. From both business and diplomatic group' this emerges a new phenomenon among many world citizens, though officially have a certain nationality status, but their mobility is very dynamic, it seems that it becomes a kind of global free citizens make a move to many places in all the world.

Fourth, in so many literature concerning corporatism state, especially in some states applying federal arrangement procedure, known that there is a concept of corporate federalism as a system arranging political representative principle based on a certain race consideration or cultural subdividing of residents. A division of English speaking community group and French speaking community group in Canada, a group of Dutch speaking community and German of speaking community in Belgium, and political representative principles of certain term in parliament room in Austrian, can be called by corporate federalism in wide meaning. The cultural and ethnical group considered as by a separate entity law having autonomous politics rights and so has the rights to a democratic representation in parliament institution. Autonomous entity arrangement seems needed by as an autonomous area or as a separate division state, though the communities do not live in a certain territory. Consequently, arrangement like was this called by corporate federalism. 
The four socio-cultural phenomenon being mentioned above can be said to have very special characters and awaken our awareness regarding the cultural diversity which we inherit from the past, but at the same time generates the problem concerning the awareness of mankind's nationality which all this time is officially limited by the state's territorial boundary. Now, the time has changed. We enter the globalization era, where the ties of a state's formal boundary have been loosen. Beside the ties of the formal nationality law, the identity awareness will be influenced by the cultural historical factors which also have been considered in comprehending the human's relation phenomenon in the future (Barendt, Eric, 1998:78-90). Therefore, the dimensions of human rights in the present day cannot be discharged off from the changes of various understanding patterns inside those new relation patterns.

In other words, the power relation in this current time and the future, not only be seen in vertical context inside a state, that is between the government and its people, can also be seen in the context of horizontal relation as has been elaborated at the first part of this article. The horizontal relation context can happen between society groups in one state and among groups of inter-states society. In this current industrial era, the horizontal relation pattern can easily be seen as a production process in the broadest possible meaning, that also includes the understanding of production in the context of vertical power relation, where every government's policy can be conceived as a product made by the government as the producer, while the public's as the side consuming his products or its consumers. As the same thing, every company is the producer, while the product is bought and consumed by its consumer society. In other words, the consumer's rights in widest meaning can be said as a new dimension of human rights which grows and has to be protected against the possibility of misused and injustice actions in horizontal power relation between the producer side and his consumers.

This last growth of concept can be seen as the fifth generation growth of human rights concept with fundamental characteristic in understanding about the structure of horizontal power between the producer who owns all potency and opportunities to conduct an unfairness action to the consumer side who is treated unfair and injustice. All of us have to realize the changes of this power relation structure, so that we should not only focus at the possibilities of the conventional human rights violation. Only by realizing this change, we can offer the resolution in collective struggle to uphold and improve the human rights in the future.

\section{The Obligation of Protecting and Improving Human Rights}

The Human Rights concept which initially emphasizes at vertical relation, especially influenced by the history of Human Rights violation which most off all conducted by the state, either with civil and politics rights or also economic, social, and cultural rights. As its 
consequences, despite that it has been the government's duty, the main obligation of protecting and improving Human Rights lies on the government. This matter can seen from the formula of Universal Declaration of Human Rights, International Covenant about Civil and Political Rights, and also International Covenant about Economic, Social And Cultural Rights, which are the state's confession to human right as becoming the content of those three instruments. Consequently, it is the state who has the burden for the obligation of protecting and improving the Human Rights. The State's obligation affirmed in consideration "Consider" either in International Covenant about Civil and Political Rights and also International Covenant about Economic, Social and Cultural Rights. In national law, Section 28I subsection (4) Constitution 1945 expresses that protecting, improving, straightening, and accomplishing of Human Rights is the state's responsibility, especially the government.

With the expanded Human Rights concept which also includes the horizontal relations produces the extension of Human Rights violation category and its actors. The rights to receive information and participation in the development, for example, are not only the state's obligation, but also become the corporation's responsibility which is in its activity connected with the society life. The companies' existence should, willing or unwilling, brings an impact to the society life which frequently becomes the decrease of human rights.

The contiguity between corporation with Human Rights at least related to the rights to have healthy and clean environment, rights to the availability and accessibility of natural resources and worker rights. Broadly, the structure of horizontal power relation between the producer also has the potency and opportunity for unfairness action to the consumer side which is possibly treated unfair and injustice.

Hence, the Human Rights violation cannot only be conducted by the state. In horizontal power relationship patterns, the opportunity of Human Rights violation can be broader and its actor can also include the non-state actor of non state, either individual or a corporation. Therefore, it is the time that the obligation and responsibility for the protection and improvement of Human Rights are on every individual and corporation. This matter has also been expressed in "Declaration on the Right and Responsibility of Individuals, Groups, and Organs of Society to Promote and Protect Universally Recognized Human Rights and Fundamental Freedom" in 1998.

The obligation and responsibility become very important progressively consider the main problem faced by the mankind which is no longer simply human evilness, genocide, or war crime. The problem faced by the mankind today is more fundamental such as poverty and undeveloped which should consider as the result of exploitation or at least the unwariness of other side of the world which experience of properties and progress. The corporation obligation and responsibility are in the form of Corporate Social Responsibility especially in Community Development, which should not simply mean as an effort to build an image. The obligation and responsibility are born from human commitment. That obligation is also born 
because of the corporation activists' awareness that corporation activity, directly are not, have created the lameness, poverty, and undeveloped. Without the corporation's role, the effort to create a better world, a world which is free from hunger and undeveloped will be difficult to do recalling the corporation's power which frequently exceeds the ability of a state.

\section{F. CLOSING}

From the analysis of this research, it can be concluded as follows. First, the state is obliged to have a strategic and big role in applying (implementing) Democracy and Human Rights so that it needs to give the assessment between the concept and its realization. Second, the state's participation in giving input and suggestion which are compiled by the state's institutions (Legislative) and executed by the Executive which is expected to give a big influence and impact in improving the people prosperity.

Furthermore, for that reason, the National Commission of Human Rights should improve its role and also maximize its strong influence and manifestly be seen by the people. Nevertheless, in making a change it requires to entangle the society participation as many as possible.

\section{BIBLIORGRAPHY:}

Asshiddiqie, Jimly. 2005. Konstitusi \& Konstitusionalisme Indonesia (Costitution and Constitutionalism of Indonesia). Edisi Revisi. Jakarta: Konstitusi Press,.

.2005. Hukum Tata Negara dan Pilar-Pilar Demokrasi (Constitutional Law and Democracy Pilars). Jakarta: Konstitusi Press,.

Barendt, Eric, 1998. An Introduction to Constitutional Law, (New York: Oxford University Press.

Ferejohn, John, Jack N. Rakove, and Jonathan Riley (eds). 2001. Constitutional Culture and Democratic Rule. Cambridge: Cambridge University Press.

Fukuyama, Francis. 2005. Memperkuat Negara: Tata Pemerintahan dan Tata Dunia Abad 21. (State Building: Governance and World Order in the $21^{\text {st }}$ Centur). Penerjemah: A. Zaim Rofiqi, Jakarta: Gramedia Pustaka Utama.

Giddens, Anthony. 2003. The Constitution of Society: Teori Strukturasi untuk Analisis Sosial. Judul Asli: The Constitution of Society: The Outline of the Theory of Structuration. Penerjemah: Adi Loka Sujono. Pasuruan; Penerbit Pedati,.

Hart, H.L.A, 2013. Konsep Hukum (Concept of Law), Cetakan ke V. Penerjemah: M. Khozim, (Bandung: Nusa Media.

Huntington, Samuel P. 1991. The Third Wave: Democratization in the Late Twentieth Century. Norman: University of Oklahoma Press,.

International Forum on Globalization, 2003. Globalisasi, Kemiskinan dan Ketimpangan (Globalization, Poverty, and Inequality) ctk. Pertama, Yogyakarta: Cindelaras Pustaka 


\section{Rakyat Cerdas (CPRC), ,.}

Jim Ife, 2001. Human Rights and Social Work, Toward Rights Based Practice, ctk. Pertama, Cambridge: Cambridge University Press,

Kelsen, Hans. 2013. Teori Hukum Murni (Law Theory),. Bandung: Nusa Media.

Mansour Fakih dkk, 2003. Menegakkan Keadilan dan Kemanusiaan, Pegangan untuk Membangun Gerakan Hak Asasi Manusia (Enforcement of Justice and Humanity, A Handbook for Building a Human Rights Movement), Yogyakarta: ctk. Ketiga, Insist.

Muladi (ed.), 2005. Hak Asasi Manusia, Hakekat, Konsep dan Implikasinya dalam Perspektif Hukum dan Masyarakat (Human Rights, Nature, Concepts, and Their Implications in The Perspective of Law and Society), Bandung: ctk. Pertama, Refika Aditama.

Peter Davies (peny.), 1994. Hak Asasi Manusia, Sebuah Bunga Rampai, terj. A. Rahman Zainuddin. Jakarta: ctk. Pertama, Yayasan Obor Indonesia, ,

Sabine, George H. 1961. A History of Political Theory. Third Edition. New York-Chicago-San Fransisco-Toronto-London: Holt, Rinehart and Winston,.

Satya Arinanto. 2003. Hak Asasi Manusia dalam Transisi Politik di Indonesia (Human Rights in The Political Transition). Jakarta: ctk. Pertama, Pusat Studi Hukum Tata Negara Fakultas Hukum Universitas Indonesia.

Suseno, Franz Magnis. 1999. Etika Politik: Prinsip-prinsip Moral Dasar Kenegaraan Modern (Political Ethics: The Basic Moral Principles of Modern State). Jakarta: PT Gramedia Pustaka Utama.

Walter Laqueur. 1979.Barry Rubin, The Human Rights Reader. New York: ctk. Pertama, New American Library.

\section{Internet:}

Antonio Pradjasto, "Monitoring Hak-hak Ekonomi, Sosial dan Budaya", dalam www.sekitarkita.com, 09 Januari 2005. 